\title{
APLIKASI DATA PELANGGAN BERBASIS JAVA DAN MOBILE PADA PT. PLN (PERSERO) AREA SEMARANG
}

\author{
Rizaldi Habibie. ${ }^{1)}$, R. Rizal Isnanto. ${ }^{2)}$, Rinta Kridalukmana. ${ }^{2)}$ \\ Program Studi Sistem Komputer, Fakultas Teknik, Universitas Diponegoro \\ Jalan Prof. Sudharto, Tembalang, Semarang, Indonesia \\ E - mail : rizaldihabibie@yahoo.com
}

\begin{abstract}
In modern times, like today, the role of software or applications that run on top of the platform is very important. This is because almost all of the work done by the people, made by the software or application. Applications can be used to assist in the processing of data and upload the final report. Data recorded previously processed by the paper can be recorded and processed by the application so that more efficiently.

PT. PLN (Persero) Semarang District State electricity company has many customers in the city of Semarang. Customer data belonging to this company has not been processed in digital form. This causes the data of regular visits undertaken are not directly connected with customer data, owned so inefficient and requires a long process in the course of the report. Thus, it takes an application that can help in the treatment of customer data, data of visited consumer, and generate reports .

Customer data Java-based and mobile applications for PLN (Persero) Semarang District State intended for the treatment of customer data, data of visited connsumer and generate reports. The application consists of two application. The first applications developed using the programming language Java, which can run on the operating system Windows. The second application was designed and implemented using the framework ionic, which can run on the Android operating system. This application uses MySQL as a database management system, which is used for data storage media.
\end{abstract}

Keywords: Java Programming Language, MySQL , Ionic Framework, Android.

\section{PENDAHULUAN}

\section{A. LATAR BELAKANG}

BUMN (Badan Usaha Milik Negara) merupakan badan usaha yang dimiliki oleh negara untuk memenuhi kebutuhan penduduk sebagai penunjang pengembangan suatu negara. Indonesia memiliki banyak BUMN yang bergerak dalam berbagai bidang. Salah satu BUMN yang ada adalah PT. PLN (Persero). Perusahaan ini bertugas untuk menyediakan pasokan listrik bagi seluruh wilayah yang ada di Indonesia. Pasokan listrik pada Kota Semarang, dikelola oleh PT. PLN (Persero) Area Semarang.

Di Kota Semarang terdapat banyak perusahaan atau instansi yang menggunakan jasa PT. PLN (Persero) Area Semarang. Mulai dari perusahaan yang bergerak dalam bidang industri hingga instansi yang bergerak dalam bidang pendidikan menjadi pelanggan PT. PLN (Persero) Area Semarang. Demi meningkatkan pelayanan terhadap para pelanggan ini, PT. PLN (Persero) Area Semarang senantiasa melakukan kunjungan rutin kepada pelanggan. Kunjungan ini bertujuan untuk melakukan pencatatan identitas pelanggan dan menerima kritik dan saran yang diberikan oleh pelanggan.
Data ini harus dikelola dengan baik agar dapat dimanfaatkan secara.

Data Pelanggan pada PT. PLN (Persero) Area Semarang dicatat dengan menggunakan aplikasi Microsoft Excel. Hal ini menyebabkan data tidak mudah untuk diakses terutama saat melakukan kunjungan kepada pelanggan. Data kunjungan harus dicatat secara manual dengan formulir yang dibawa oleh petugas. Data hasil kunjungan akan dibawa oleh petugas ke kantor untuk di catat ulang. Laporan hasil kunjungan pun dibuat dengan cara manual yaitu dengan mendesain laporan dengan menggunakan Aplikasi Corel Draw. Hal ini tentu saja tidak efisien dan menghabiskan waktu.

Ilmu pengetahuan serta teknologi informasi dan komunikasi saat ini telah mengalami perkembangan yang sangat pesat. Faktor ketersediaan informasi dan kemudahan dalam mengakses informasi yang dapat diakses dimanapun dan kapanpun inilah yang menjadikan pemanfaatan teknologi diterapkan hampir diberbagai bidang. Informasi dan komunikasi harus dapat diakses dengan mudah. Kemudahan yang ditawarkan inilah yang membuat teknologi informasi diterapkan di hampir setiap aspek kehidupan manusia. Penerapan teknologi informasi ini akan sangat membantu perusahan dalam melakukan pendataan informasi pelanggan.

Dengan adanya penjelasan diatas, maka penulis merancang aplikasi pencatatan data pelanggan berbasis Java dan Mobile yang diharapkan mampu memudahkan pegawai dalam melakukan pencatatan data pelanggan PT. PLN (Persero) Area Semarang dan membuat laporan data keluhan pelanggan serta dapat digunakan untuk memanajemen data pelanggan bagi perusahaan.

\section{B. RUMUSAN MASALAH}

Bagaimana mendesain sebuah aplikasi yang dapat memudahkan karyawan atau pegawai dalam melakukan pencatatan data pelanggan, data hasil kunjungan serta data keluhan pelanggan dan bagaimana membuat sebuah aplikasi yang dapat berjalan pada Sistem Operasi Windows dan sebuah aplikasi yang dapat berjalan pada smartphone dengan Sistem Operasi Android?

\section{BATASAN MASALAH}

Dalam penulisan tugas akhir ini, penulis membatasi pembahasan masalah sebagai berkut :

1. Aplikasi yang dibuat pada tugas akhir ini hanya membahas sisi klien yang berjalan pada sistem operasi Windows dan Android.

2. Aplikasi bergerak dijalankan pada Sistem Operasi Android. 
3. Aplikasi Desktop dijalankan pada Sistem Operasi Windows.

4. Perancangan aplikasi desktop menggunakan bahasa pemrograman JAVA dengan editor Netbeans IDE.

5. Perancangan aplikasi bergerak menggunakan framework IONIC dengan editor Sublime.

6. Basis data yang digunakan adalah MySQL.

7. Perancangan hanya membahas fungsionalitas dari aplikasi yang dirancang.

8. Aplikasi ini hanya bersifat purwarupa yang nantinya dapat dikembangkan sesuai dengan kebutuhan

9. Lingkungan pengembangan aplikasi ini adalah PT. PLN (PERSERO) Area Semarang.

\section{TUJUAN PENELITIAN}

1. Membuat aplikasi bergerak yang dapat membantu petugas lapangan dalam mencatat data hasil kunjungan.

2. Membuat aplikasi yang dapat membantu petugas di kantor dalam memanajemen data pelanggan dan data kunjungan.

3. Membuat aplikasi yang dapat membantu mengelola data keluhan yang masuk.

\section{TINJAUAN PUSTAKA}

\section{A. TEKNOLOGI INFORMASI}

Terdapat beberapa definisi tentang teknologi informasi. Menurut Haag dan Ken ${ }^{[8]}$ Teknologi informasi adalah seperangkat alat yang membantu anda bekerja dengan informasi dan melakukan tugas-tugas yang berhubungan dengan pemrosesan informasi. Sedangkan menurut Martin ${ }^{[12]}$ Teknologi informasi tidak hanya terbatas pada teknologi komputer (perangkat keras dan perangkat lunak) yang digunakan untuk memproses dan menyimpan informasi, melainkan juga mencakup teknologi komunikasi untuk mengirimkan informasi. Menurut William dan Sawyer, Teknologi Informasi adalah teknologi yang menggabungkan komputasi (komputer) dengan jalur komunikasi berkecepatan tinggi yang membawa data, suara dan video ${ }^{[2]}$.

Dari beberapa pengertian tersebut, terlihat bahwa secara implisit maupun eksplisit teknologi informasi tidak sekedar berupa teknologi komputer, namun juga mencakup teknologi telekomunikasi. Dengan kata lain, teknologi informasi adalah gabungan antara teknologi komputer dan teknologi telekomunikasi.

\section{B. APLIKASI}

Aplikasi memiliki beberapa pengertian. Menurut Febrian, Aplikasi merupakan program siap pakai yang digunakan manusia dalam melakukan pekerjaan menggunakan komputer ${ }^{[6]}$. Sedangkan menurut Hartono Jogiyanto, Aplikasi merupakan program yang berisikan perintah-perintah untuk melakukan pengolahan data ${ }^{[9]}$. Jogiyanto menambahkan, aplikasi secara umum adalah suatu proses dari cara manual yang di transformasikan ke komputer dengan membuat sistem atau program agar data diolah lebih berdaya guna secara optimal. Menurut Dhanta, aplikasi adalah software yang dibuat oleh suatu perusahaan komputer untuk mengerjakan tugas-tugas tertentu, misalnya Microsoft Word dan Microsoft Excel [5]. Anisiyah memiliki definisi tersendiri mengenai aplikasi. Menurut anisiyah, aplikasi adalah penerapan, penggunaan atau penambahan data ${ }^{[1]}$.

Berdasarkan pengertian-pengertian diatas, maka dapat disimpulkan bahwa aplikasi adalah suatu perangkat lunak yang berjalan diatas suatu sistem operasi dimana perangkat lunak tersebut berisi perintah-perintah yang berfungsi untuk melakukan berbagai pekerjaan atau tugas tertentu yang berhubungan dengan pengolahan data.

\section{PERANGKAT BERGERAK}

Menurut Gartner (2003), perangkat bergerak secara umum dapat diklasifikasikan dalam 2 kategori, yaitu :

1. Telepon selular dengan peningkatan kemampuan komputasi, termasuk menampilkan grafik dan kemampuan berinteraksi dengan grafik (seperti : smartphone dan communicator).

2. Komputer portabel, yang dapat diintegrasikan dengan kemampuan komunikasi audio-video (contoh : PDA).

Pada umumnya perangkat bergerak yang digunakan untuk aplikasi pada sisi klien memiliki sebuah sistem operasi yang memberi penggunanya sebuah interface atau antarmuka dan fungsi untuk mengontrol perangkat. Ada bermacammacam sistem operasi pada perangkat bergerak antara lain : Palm OS, Linux, Android, Symbian, Windows Mobile, iOS dan Blackberry OS. ${ }^{[15]}$

\section{BAHASA PEMROGRAMAN JAVA}

Tahun 1991 sekelompok insinyur SUN dipimpin oleh Patrick Naughton dan james Gosling ingin merancang bahasa komputer untuk perangkat konsumer seperti cable TV Box. Karena perangkat tersebut tidak memiliki banyak memori, bahasa harus berukuran kecil dan mengandung kode yang mudah dimengerti. Karena platform pada setiap prosesor berbeda, maka bahasa harus bebas dari platform manapun. Proyek diberi nama kode "Green". [18]

Kebutuhan untuk fleksibilitas, kecil, mudah dimengerti dan kode yang netral terhadap platform mengantar tim mempelajari implementasi Pascal yang pernah dicoba. Niklaus Wirth, pencipta bahasa Pascal telah merancang bahasa portabel yang menghasilkan intermediate code untuk mesin hipotesis. Mesin ini disebut mesin maya (virtual machine). Kode ini kemudian dapat digunakan di sembarang mesin yang memiliki interpreter. Proyek Green menggunakan mesin maya untuk mengatasi masalah utama yaitu netral terhadap arsitektur mesin.

Karena orang-orang pada proyek Green berbasis $\mathrm{C}++$ dan bukan Pascal maka kebanyakan sintaks diambil dari $\mathrm{C}++$. Tim juga mengadopsi pemrograman berorientasi objek bukan prosedural. Mulanya bahasa yang diciptakan diberi nama "OAK" oleh James Gosling yang mendapat inspirasi dari sebuah pohon yang berada pada seberang kantornya. Tapi karena nama OAK telah ada sebelumnya, SUN mengantinya dengan JAVA. Nama JAVA terinspirasi pada saat mereka sedang menikmati secangkir kopi disebuah kedai kopi yangn kemudian dengan tidak sengaja salah satu dari mereka menyebutkan kata JAVA yang mengandung arti asal biji kopi. Mereka sepakat memberi nama proyek tersebut dengan nama JAVA. Produk pertama proyek Green adalah Star 7 (*7), sebuah kendali jarak jauh yang sangat cerdas. Pada saat yang sama, implementasi WWW dan Internet sedang mengalami perkembangan pesat. Anggota dari proyek Green juga menyadari bahwa JAVA dapat digunakan pada pemrograman internet, maka penerapan selanjutnya mangarah menjadi teknologi yang berperan di web.

\section{E. BASIS DATA}

Menurut Conolly, Basis data adalah kumpulan data yang terbagi dan terhubung secara logika dan merupakan deskripsi dari data yang dirancang untuk memnuhi kebutuhan informasi [4]. Menurut C.J Date, Basis data terdiri dari beberapa kumpulan data tetap yang digunakan oleh sistem aplikasi untuk diberikan kepada perusahaan ${ }^{[3]}$. Menurut 
Kusrini Basis data adalah sekumpulan data yang memiliki hubungan satu sama lain atau memiliki relasi ${ }^{[11]}$.

Data adalah fakta mengenai objek, orang dan lain-lain. Data dapat dinyatakan dengan nilai. Berdasarkan pengertianpengertian tersebut diatas, maka dapat disimpulkan bahwa basis data merupakan suatu kumpulan data yang memiliki hubungan satu sama lain dan dibuat atau dirancang dengan tujuan memenuhi kebutuhan akan informasi dari suatu organisasi atau perusahaan.

\section{Entitas}

Basis data memiliki beberapa komponen antara lain :

Entitas merupakan penerapan integritas data pada tabel basis data agar setiap baris pada suatu entitas bersifat unik yang disebut dengan primary key sehingga data yang satu dengan yang lainnya berbeda

2. Atribut

Setiap entitas pasti memiliki atribut yang mendeskripsikan karakteristik dari entitas tersebut. Penentuan atau pemilihan atribut yang relevan bagi sebuah entitas merupakan hal yang penting dalam merancang sebuah model data.

\section{F. DATABASE MANAGEMENT SYSTEM (DBMS)}

Menurut Kristanto, Database Management System adalah kumpulan data yang saling berkaitan bersama dengan program untuk dikelola ${ }^{[10]}$. DBMS terdiri dari basis data dan perangkat lunak pengelola data yang digunakan untuk menambah, menghapus, melihat dan mengubah data. Sedangkan menurut Connoly dan Begg, Database Management System adalah suatu sistem perangkat lunak yang memungkinkan pengguna untuk mendefinisikan membuat, memelihara dan mengatur akses ke basis data ${ }^{[4]}$.

Berdasarkan definisi definisi tersebut, kita dapat menyimpulkan bahwa Database Management System adalah sebuah perangkat lunak yang dibuat untuk mengelola basis data. Contoh DBMS antara lain : MySQL, Oracle, SQL Server dan lain-lain.

\section{G. MySQL}

MySQL merupakan sebuah perangkat lunak pembuat dan pengelola basis data yang bersifat open source dimana perangkat lunak ini berjalan disemua platform baik linux maupun Windows. MySQL merupakan program yang dapat digunakan untuk aplikasi multiuser (banyak pengguna).

MySQL didistribusikan secara gratis dibawah lisensi GPL (General Public Licence ). Setiap orang bebas untuk menggunakan MySQL namun tidak boleh dijadikan produk turunan yang bersifat komersial.

\section{H. PERANCANGAN BASIS DATA}

Menurut Conolly dan Begg, perancangan basis data adalah proses untuk menciptakan desain basis data yang akan mendukung kebutuhan dan tujuan suatu perusahaan ${ }^{[4]}$. Perancangan basis data dibagi menjadi tiga tahap, antara lain :

\section{Conceptual Database Design}

Conceptual database design adalah suatu proses membangun suatu model berdasarkan informasi yang didapat dari perusahaan atau organisasi dan digunakan oleh perusahaan atau organisi itu sendiri tanpa pertimbangan perencanaan fisik. Pada tahap ini langkah-langkah yang dilakukan adalah mengidentifikasi jenis entitas, mengidentifikasi jenis relasi, mengidentifikasi dan menghubungkan atribut dengan entitas atau relasi, menentukan atribut domain, menentukan atribut candidate key dan primary key, mempertimbangkan penggunaan enhance modeling concepts dan mengecek adanya redudansi data.

\section{Logical Database Design}

Merupakan proses pembuatan model informasi yang digunakan pada perusahaan berdasarkan pada model data yang spesifik, namun tidak bergantung pada DBMS yang digunakan dan tanpa pertimbangan fisik yang lainnya.

\section{Physical Database Design}

Merupakan proses untuk menghasilkan gambaran dari implementasi basis data pada tempat penyimpanan, menjelaskan dasar dari relasi, organisasi file dan indeks yang digunakan unruk efisiensi data dan menghubungkan beberapa integrity constaints dan tindakan keamanan. Pada tahap ini basis data sudah berupa tabel-tabel yang siap untuk digunakan.

\section{ANDROID}

Android merupakan sistem operasi telepon seluler yang tumbuh di tengah sistem operasi lainnya yang berkembang dewasa ini. Sistem Operasi lainnya seperti Windows Mobile, iOS-iPhone, Symbian, dan masih banyak lagi juga menawarkan kekayaan isi dan keoptimalan berjalan di atas perangkat keras yang ada. Akan tetapi, sistem operasi yang ada ini berjalan dengan memprioritaskan aplikasi inti yang dibangun sendiri tanpa melihat potensi yang cukup besar dari aplikasi pihak ketiga. Oleh karena itu adanya keterbatasan dari aplikasi pihak ketiga untuk mendapatkan data asli ponsel, berkomunikasi antar proses serta keterbatasan distribusi aplikasi pihak ketiga untuk platform mereka.

\section{ANALISA DAN PERANCANGAN SISTEM}

\section{A. TAHAPAN PENGEMBANGAN METODOLOGI}

Dalam proses pengembangan sebuah perangkat lunak, terdapat beberapa metodologi yang dapat digunakan. Aplikasi Data Pelanggan PT. PLN (PERSERO) Area Semarang Berbasis Java dan Mobile ini dirancang menggunakan metodologi pengembangan yang diadopsi dari metodologi waterfall. Metodologi ini dipilih karena proses pengembangannya dilakukan secara bertahap sehingga tidak terfokus pada tahapan tertentu. Gambar dibawah ini menunjukan model metodologi yang digunakan untuk mengembangkan aplikasi.

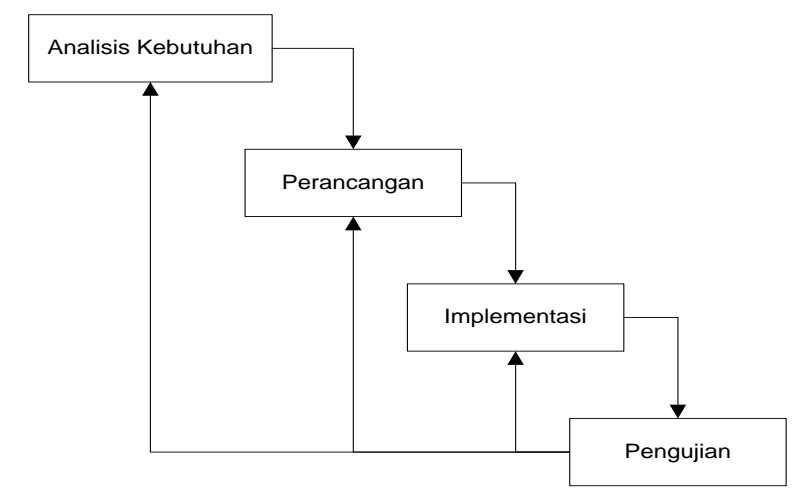

Gambar 1 Metodologi pengembangan yang diadopsi dari metologi waterfall

\section{B. DESAIN SISTEM PERANGKAT LUNAK}

Tahapan yang dilakukan dalam pembuatan perangkat lunak harus jelas dan terstruktur. Oleh karena itu, digunakanlah permodelan perangkat lunak. Untuk mendapatkan permodelan perangkat lunak yang terstruktur, kita menggunakan Diagram Alir Data untuk mengtahui aliran data dalam sistem. Permodelan lain yang digunakan adalah Diagram Alir yang berguna untuk mengetahui alur kerja sistem. Selain itu, Relasi Entitas juga digunakan untuk menggambarkan struktur basis data. 


\section{DIAGRAM ALIR DATA}

Diagram alir data merupakan perangkat-perangkat analisis dan perancangan yang terstruktur. Diagram ini berfungsi untuk menggambarkan arus data yang mengalir dalam sistem sehingga dapat membantu memahami sistem secara logika dan terstruktur.

Diagram konteks merupakan diagram yang menggambarkan kondisi sistem yang ada, baik masukan maupun keluaran serta menyertakan terminator yang terlibat dalam penggunaan sistem. Diagram ini merupakan diagram dengan tingkatan tertinggi dalam diagram aliran data dan hanya memuat satu proses, serta menunjukkan sistem secara keseluruhan. Proses tersebut diberi nomor nol. Semua entitas eksternal yang ditunjukkan pada diagram konteks berikut menunjukkan aliran data menuju dan dari sistem.

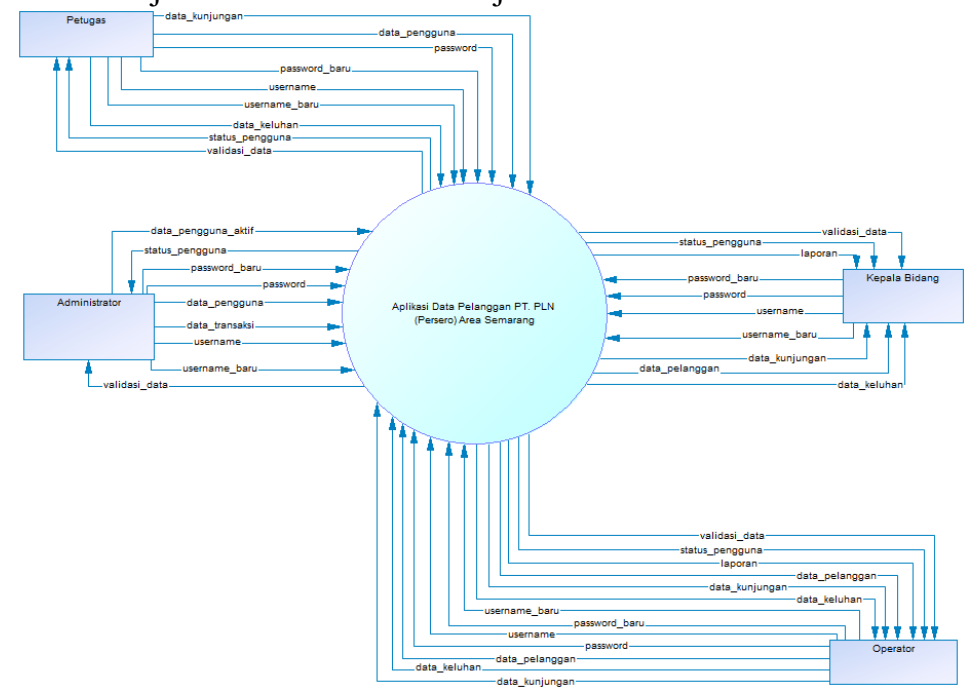

Gambar 2. Diagram konteks

Diagram konteks diatas merupakan diagram konteks dari aplikasi data pelanggan. Dari diagram tersebut dapat diketahui bahwa sistem ini memiliki 4 buah entitas eksternal yaitu petugas, administrator, operator dan kepala bidang. Administrator memiliki hak akses mengontrol pengguna. Operator bertugas memasukkan data pelanggan dan data kunjungan. Petugas bertugas memasukkan data kunjungan dan juga data keluhan apabila terdapat keluhan dari pelanggan.

Data pelanggan ini terdiri dari data identitas pelanggan dan data yang berhubungan dengan listrik yang digunakan. Sedangkan data kunjungan berisi data hasil kunjungan petugas seperti tanggal dilakukan kunjungan, hasil kunjungan dan keluhan yang disampaikan pelanggan saat kunjungan berlangsung. Data keluhan dibagi menjadi lima kategori, yaitu kualitas tegangan, pelayanan gangguan, pelayanan pelanggan, pembacaan meter dan lain lain. Berikut ini adalah diagram alir data level 1 pada proses 1 yaitu proses ubah username dan password:

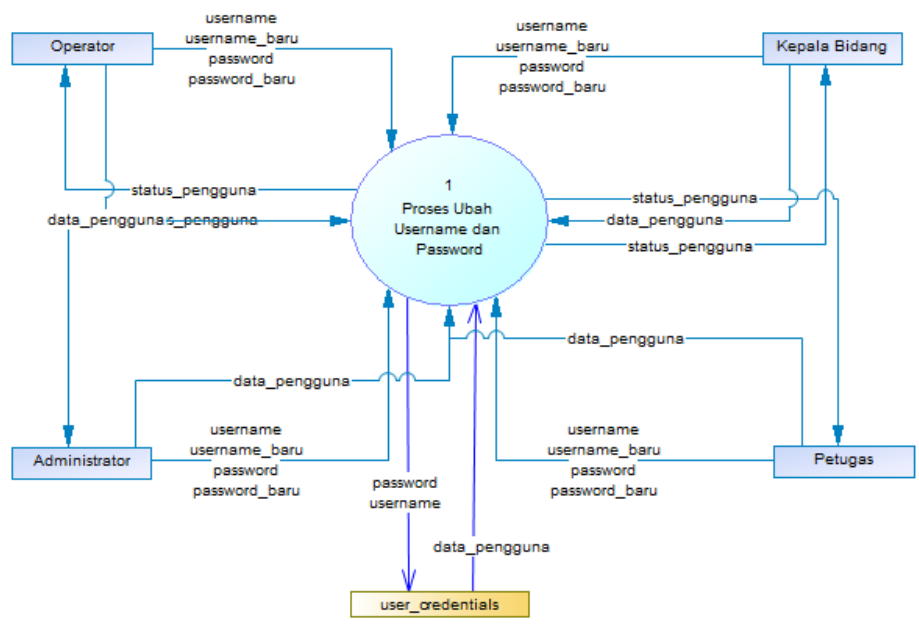

Gambar 3 Diagram alir data level 1 proses 1

Terdapat 5 buah masukan yang diberikan oleh pengguna aplikasi. Masukan tersebut antar lain data_pengguna, username, username_baru, password dan password_baru. Username dan password akan digunakan oleh sistem untuk autentifikasi pengguna yang akan mengubah username dan password. Berikut ini adalah diagram alir data level 1 pada proses 2 yaitu proses olah data pelanggan :

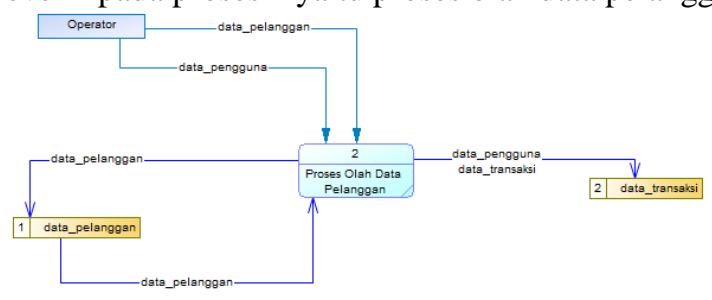

Gambar 4 Diagram alir data level 1 proses 2

Pada proses in terdapat dua buah masukan yang diterima oleh sistem. Masukan tersebut antara lain data_pelanggan dan data_pengguna. Berikut ini adalah diagram alir data level 1 pada proses 3 yaitu proses olah data pengguna:

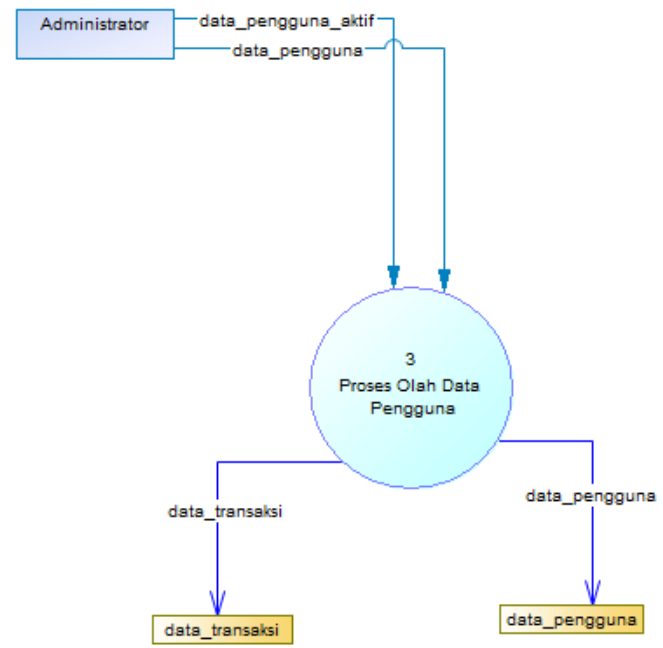

Gambar 52 Diagram alir data level 1 proses 3

Pada diagram alir yang ditunjukkan oleh gambar 3.12 terdapat dua buah masukan yang diberikan pada sistem. Masukan yang pertama adalah data_pengguna_aktif. Masukan ini berfungsi untuk mengidentifikasi pengguna yang sedang menggunakan aplikasi. Masukan data_pengguna merupakan data pengguna yang diberikan hak akses untuk menggunakan 
aplikasi. Berikut ini merupakan diagram alir data level 1 pada proses 4 yaitu buat laporan

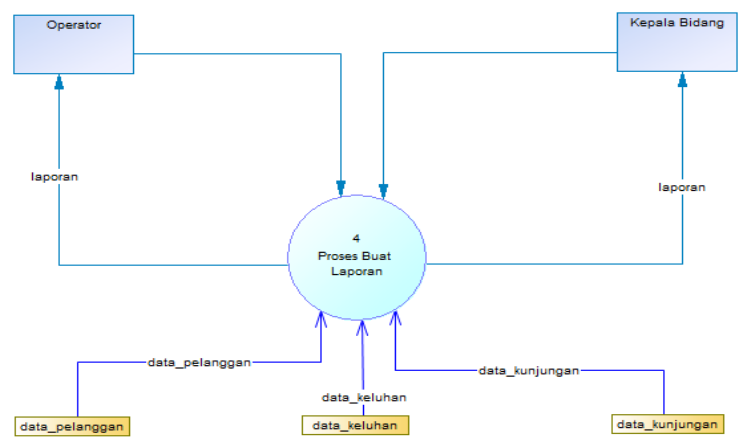

Gambar 6 Diagram alir data level 1 proses 4

Pada proses 4 , tidak ada masukan yang diberikan pada sistem. Hanya perintah untuk mencetak laporan. Berikut ini adalah diagram alir data level 1 pada proses 5 yaitu proses olah data kunjungan

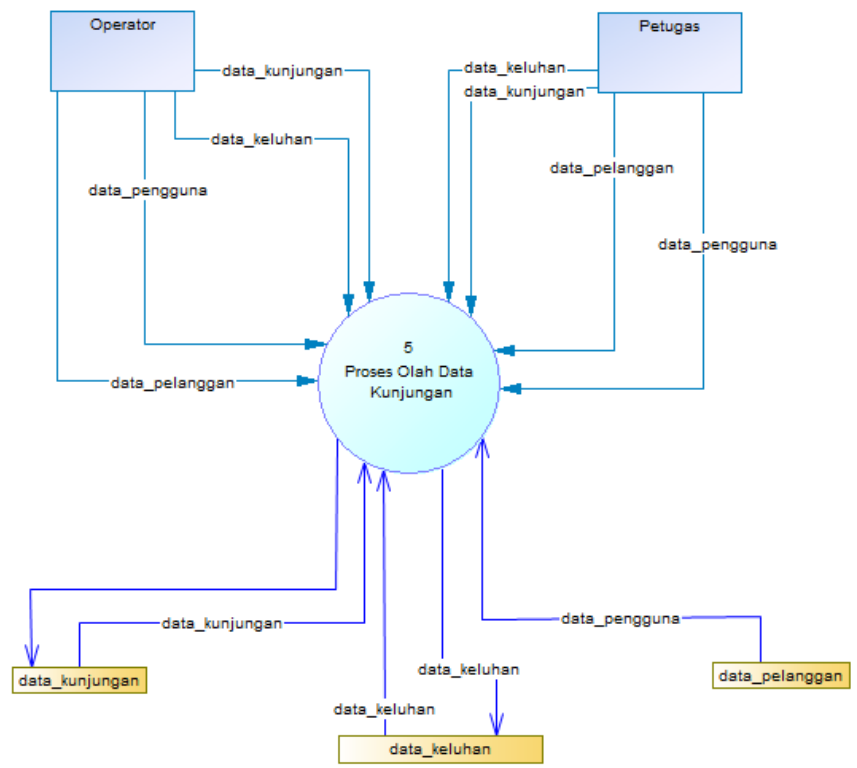

Gambar 6 Diagram alir data level 1 proses 5

Pada diagram alir data level 1 proses 5 tersebut dapat kita lihat bahwa terdapat 4 buah masukan. Masukan yang pertama yaitu data_kunjungan yang berisi data hasil kunjungan lalu data_keluhan yang menyimpan data keluhan yang diterima pada saat melakukan kunjungan. Masukan data_pelanggan berisi data pelanggan yang dikunjungi. Masukan data_pengguna berisi informasi data pengguna yang memasukkan atau mengubah data. Berikut ini adalah diagram alir data level 1 pada proses 6 yaitu proses lihat data transaksi

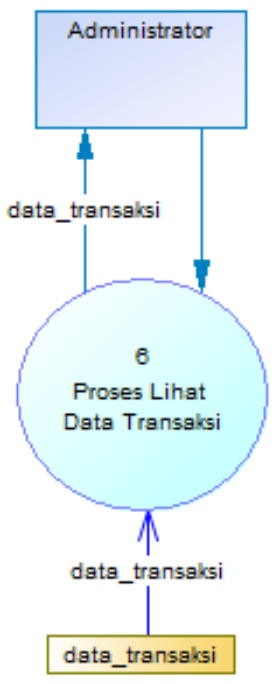

Gambar 7 Diagram alir data level 1 proses 6

Berikut ini adalah diagram alir data level 1 pada proses 7

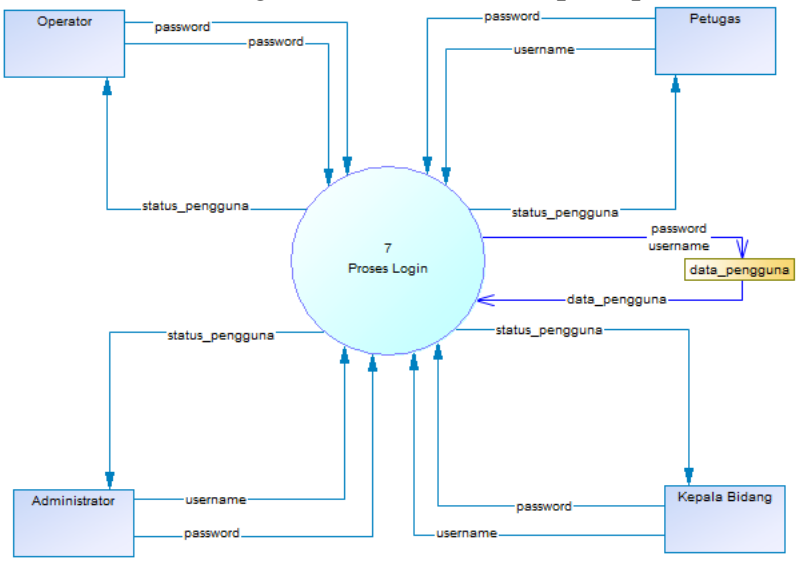

Gambar 8 Diagram alir level 1 proses 7

\section{ENTITAS DAN ATRIBUT}

Menurut barady dan Loonam (2010), entitas adalah objek yang menarik dibidang organisasi yang dimodelkan. Entitas merupakan objek yang berbeda antara yang satu dengan yang lainnya dimana objek tersebut dapat diwujudkan dalam basis data. Berikut ini adalah entitas yang dirancang untuk digunakan pada aplikasi ini:

1. Entitas pelanggan

2. Entitas kecamatan

3. Entitas kelurahan

4. Entitas kategori_keluhan

5. Entitas keluhan

6. Entitas data_kunjungan

7. Entitas Pengguna

8. Entitas Credentials

9. Entitas data_transaksi

Atribut merupakan bagian dari entitas. Setiap entitas memiliki elemen yang disebut sebagai atribut. Atribut berfungsi untuk mendeskripsiskan karakteristik dari entitas. Berikut ini adalah diagram yang menjelaskan atribut dari setiap entitas pada aplikasi data pelanggan 


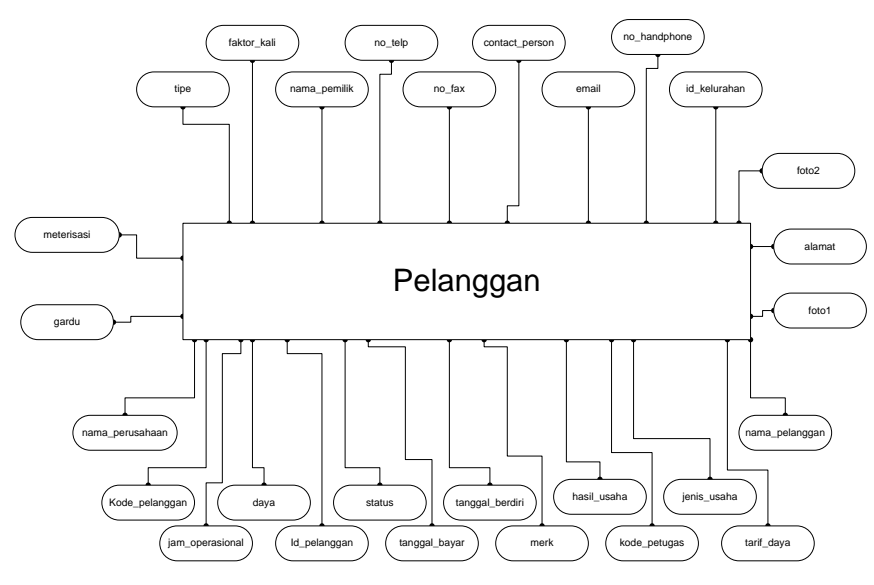

Gambar 9 Entittas dan atribut Pelanggan

Entitas data_pelanggan memiliki 28 buah atribut. Atribut-atribut itu antara lain id_pelanggan, kode_pelanggan, nama_pelanggan, nama_perusahaan, jenis_usaha, status, tanggal_berdiri, tanggal_bayar, hasil_usaha, jam_operasional, tarif_daya, daya, kode_petugas, merk, meterisasi, gardu, tipe, faktor_kali, id_kelurahan, alamat, nama_pemilik, no_telp, contact_person, no_fax, email, no_handphone, foto1, foto2.

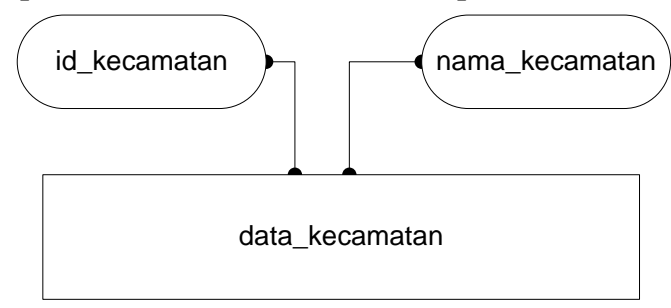

Gambar 10 Atribut dari entitas data_kecamatan

Entitas data_kecamatan memiliki dua buah atribut. Atribut-atribut tersebut antara lain id kecamatan dan nama_kecamatan.

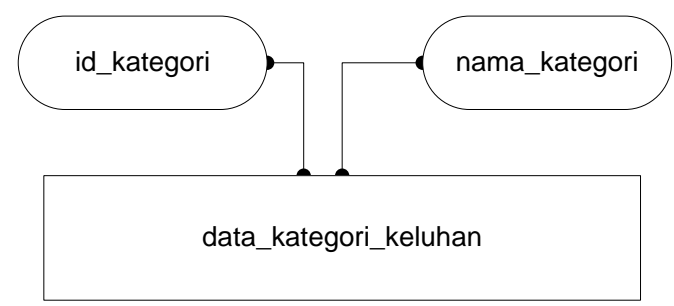

Gambar 11 Atribut dari entitas data_kategori_keluhan

Entitas data_kategori_keluhan memiliki dua buah atribut. Atribut-atribut tersebut antara lain id_kategori dan nama_kategori.

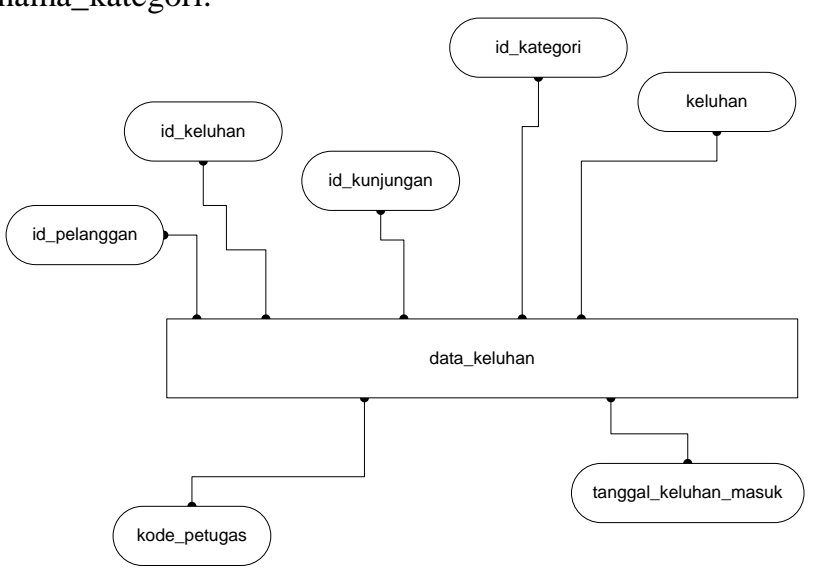

Gambar 12 Atribut dari entitas data_keluhan
Entitas data_keluhan memilki sembilan buah atribut. Atribut tersebut antara lain id_pelanggan, id_keluhan, id_kategori, keluhan, tanggal, kode_petugas dan id_kunjungan.

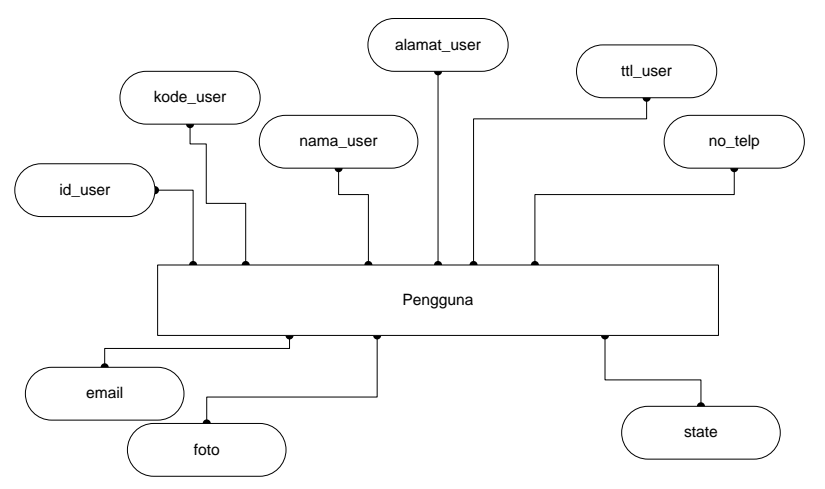

Gambar 13 Atribut dari entitas pengguna

Entitas pengguna memilki 9 buah atribut. Atribut tersebut antara lain id_user, kode_user, nama_user, alamat_user, ttl_user, no_telp, email, foto dan state.

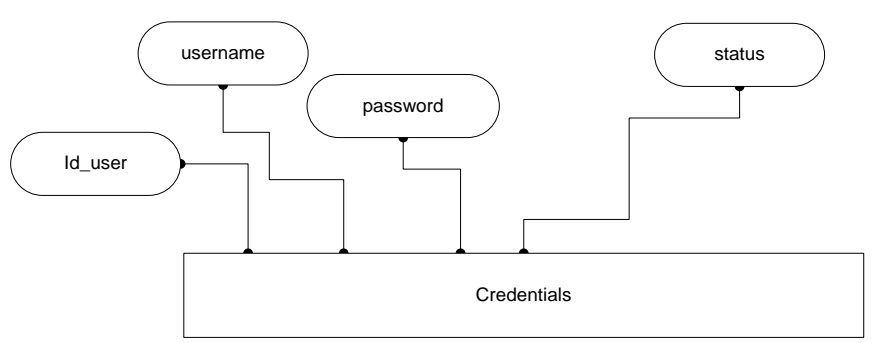

Gambar 14 Atribut dari entitas credentials

Entitas data_user memiliki 4 buah atribut. Atribut tersebut antara lain id_user, username, password, status.

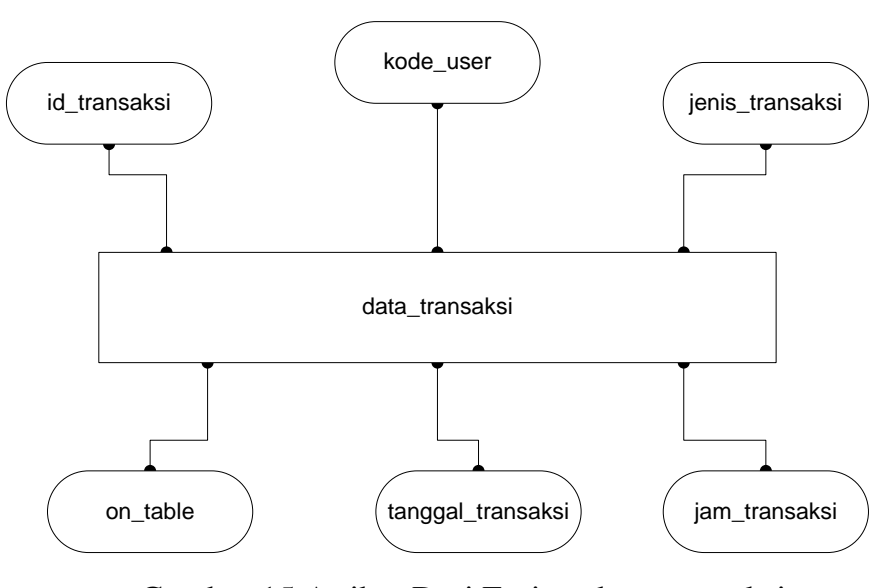

Gambar 15 Atribut Dari Entitas data_transaksi

Entitas data user memiliki 6 buah atribut. Atribut tersebut antara lain id_transaksi, kode_user, jenis_transaksi, on_table, tanggal_transaksi,jam_transaksi.

\section{DIAGRAM RELASI ENTITAS}

Diagram Relasi Entitas adalah suatu model untuk menjelaskan hubungan antar data dalam basis data bedasarkan objek-objek dasar data yang mempunyai hubungan antar relasi. Diagram relasi entitas merupakan bentuk permodelan hubungan antar data dalam sebuah basis data berdasarkan 
objek-objek dasar data yang mempunyai hubungan atau relasi. Dengan kata lain diagram ini menjelaskan hubungan antar tabel yang terdapat dalam sebuah basis data.

\section{PENGUJIAN SISTEM}

Pengujian unit dilakukan untuk mengetahui apakah fungsi fungsi pada sistem telah berjalan dengan baik dan sesuai dengan kebutuhan.Pada tahap ini dilakukan pengujian sistem dengan menggunakan metode black-box.

1. Fungsi Login

Fungsi ini merupakan aktifitas yang dilakukan ketika pengguna pertama kali menggunakan aplikasi ini. Pengujian dilakukan dengan memasukkan username dan password pada halaman login sistem. Gambar dibawah ini menunjukkan halaman login sistem

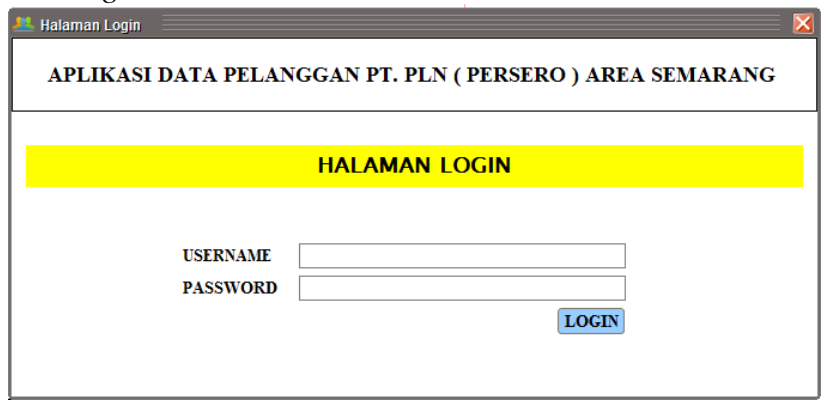

Gambar 22 Halaman login aplikasi desktop

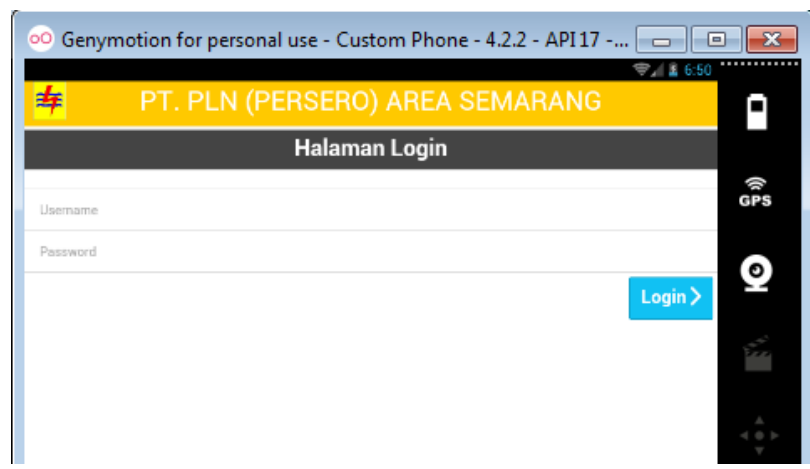

Gambar 23 Halaman login aplikasi Android

Hasil dari pengujian ini adalah ketika pengguna aplikasi memasukkan username dan password dengan benar, maka sistem akan membawa pengguna menuju halaman utama sistem. Fungsi yang terdapat pada sistem berbeda-beda tergantung hak akses yang dimiliki pengguna. Khusus untuk pengguna dengan hak akses operator hanya memiliki hak akses pada aplikasi Android. Berikut ini adalah screenshot dari halaman utama sistem.

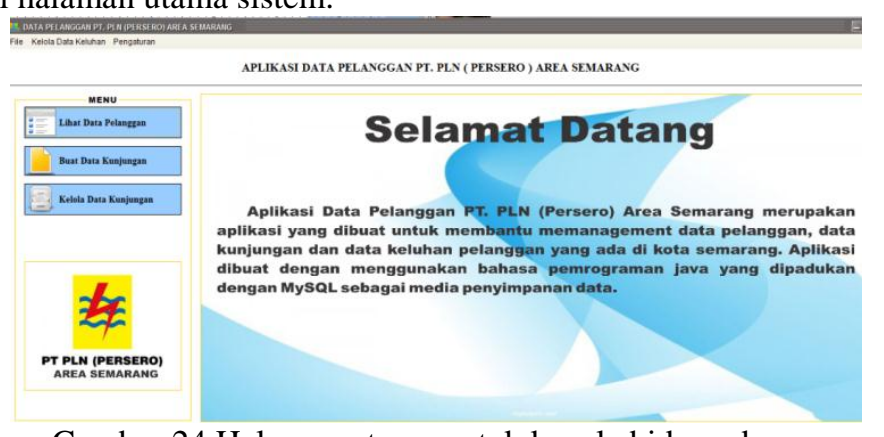

Gambar 24 Halaman utama untuk kepala bidang dan operator

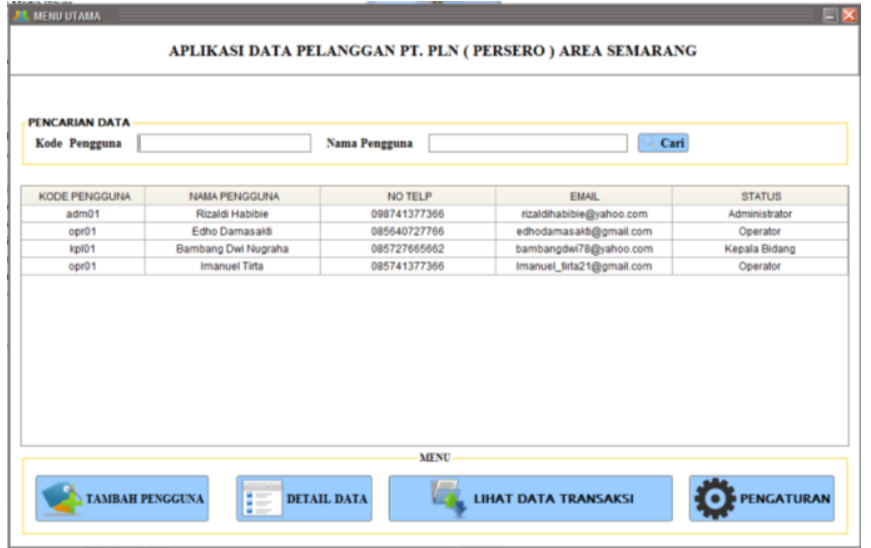

Gambar 25 Halaman utama untuk administrator

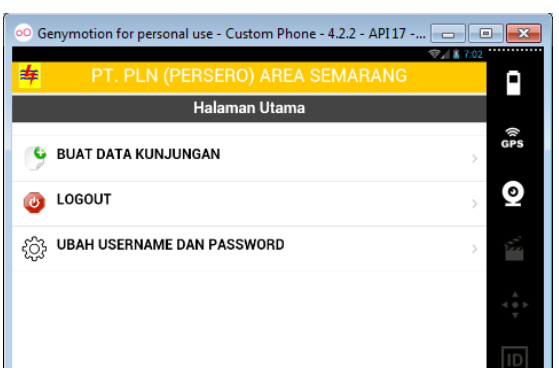

Gambar 26 Halaman utama untuk operator

Jika pengguna salah memasukkan username dan atau password maka sistem akan memberikan peringatan kegagalan proses login yang dilakukan oleh pengguna. Berikut ini tampilan pesan gagal yang ditampilkan oleh sistem

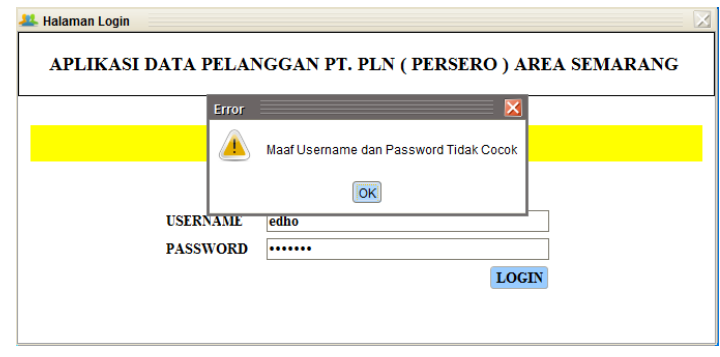

Gambar 27 Pesan gagal login pada aplikasi desktop

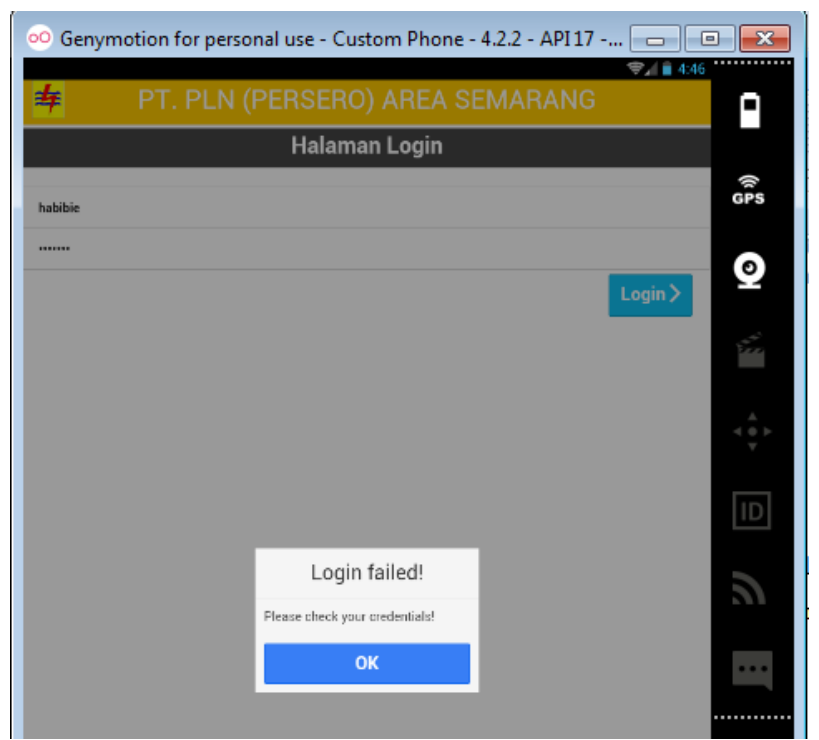

Gambar 28 Pesan gagal login pada aplikasi Android 
Tabel 4.1 Tabel Pengujian Fungsi Login

\begin{tabular}{|c|c|c|c|}
\hline $\begin{array}{c}\text { Nama } \\
\text { Pengujian }\end{array}$ & $\begin{array}{c}\text { Bentuk } \\
\text { Pengujian }\end{array}$ & $\begin{array}{c}\text { Hasil yang } \\
\text { Diharapkan }\end{array}$ & $\begin{array}{c}\text { Hasil } \\
\text { Pengujian }\end{array}$ \\
\hline $\begin{array}{c}\text { Pengujian } \\
\text { tampilan login }\end{array}$ & $\begin{array}{c}\text { Membuka } \\
\text { aplikasi }\end{array}$ & $\begin{array}{l}\text { Menampilkan } \\
\text { halaman login }\end{array}$ & Berhasil \\
\hline $\begin{array}{l}\text { Pengujian } \\
\text { login dengan } \\
\text { hak akses } \\
\text { sebagai } \\
\text { operator }\end{array}$ & $\begin{array}{c}\text { Mengisi } \\
\text { username dan } \\
\text { password } \\
\text { milik } \\
\text { pengguna } \\
\text { dengan hak } \\
\text { akses sebagai } \\
\text { operator }\end{array}$ & $\begin{array}{c}\text { Halaman } \\
\text { utama muncul } \\
\text { dengan fungsi } \\
\text { fungsi yang } \\
\text { dibuat untuk } \\
\text { operator }\end{array}$ & Berhasil \\
\hline $\begin{array}{l}\text { Pengujian } \\
\text { login dengan } \\
\text { hak akses } \\
\text { sebagai } \\
\text { kepala bidang }\end{array}$ & $\begin{array}{c}\text { Mengisi } \\
\text { username dan } \\
\text { password } \\
\text { milik } \\
\text { pengguna } \\
\text { dengan hak } \\
\text { akses sebagai } \\
\text { kepala bidang }\end{array}$ & $\begin{array}{c}\text { Halaman } \\
\text { utama muncul } \\
\text { dengan fungsi } \\
\text { fungsi yang } \\
\text { dibuat untuk } \\
\text { kepala bidang } \\
\text { (hanya fungsi } \\
\text { untuk melihat } \\
\text { data saja) }\end{array}$ & Berhasil \\
\hline $\begin{array}{l}\text { Pengujian } \\
\text { login dengan } \\
\text { hak akses } \\
\text { sebagai } \\
\text { petugas } \\
\text { lapangan }\end{array}$ & $\begin{array}{c}\text { Mengisi } \\
\text { username dan } \\
\text { password } \\
\text { milik } \\
\text { pengguna } \\
\text { dengan hak } \\
\text { akses sebagai } \\
\text { petugas } \\
\text { lapangan }\end{array}$ & $\begin{array}{c}\text { Muncul } \\
\text { peringatan } \\
\text { bahwa } \\
\text { pengguna } \\
\text { tidak memiliki } \\
\text { hak akses }\end{array}$ & Berhasil \\
\hline $\begin{array}{l}\text { Pengujian } \\
\text { login dengan } \\
\text { hak akses } \\
\text { sebagai } \\
\text { Administrator }\end{array}$ & $\begin{array}{c}\text { Mengisi } \\
\text { username dan } \\
\text { password } \\
\text { milik } \\
\text { pengguna } \\
\text { dengan hak } \\
\text { akses sebagai } \\
\text { Administrator }\end{array}$ & $\begin{array}{c}\text { Halaman } \\
\text { utama untuk } \\
\text { Administrator } \\
\text { Muncul }\end{array}$ & Berhasil \\
\hline
\end{tabular}

2. Pengujian Fungsi Menampilkan Data Pelanggan

Fungsi ini merupakan fungsi untuk menampilkan data pelanggan pada halaman data pelanggan aplikasi desktop. Hasil yang diharapkan dari pengujian ini adalah data pelanggan aktif dapat muncul pada halaman data pelanggan.

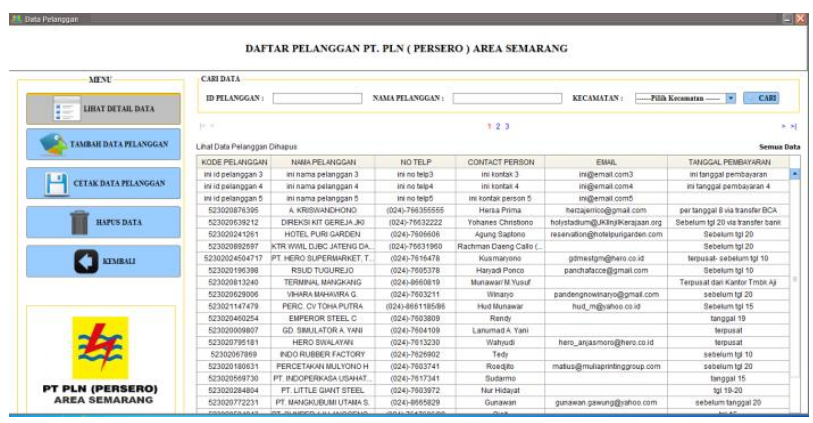

Gambar 29 Tampilan data pelanggan

Tabel 4.2 Tabel pengujian fungsi menampilakan data pelanggan

\begin{tabular}{|c|c|c|c|}
\hline $\begin{array}{c}\text { Nama } \\
\text { Pengujian }\end{array}$ & $\begin{array}{c}\text { Bentuk } \\
\text { Pengujian }\end{array}$ & $\begin{array}{c}\text { Hasil yang } \\
\text { Diharapkan }\end{array}$ & $\begin{array}{c}\text { Hasil } \\
\text { Pengujian }\end{array}$ \\
\hline
\end{tabular}

\begin{tabular}{|c|c|c|c|}
\hline $\begin{array}{c}\text { Pengujian } \\
\text { Fungsi } \\
\text { Menampilkan } \\
\text { Data }\end{array}$ & $\begin{array}{c}\text { Menampilkan } \\
\text { seluruh data } \\
\text { pelanggan } \\
\text { aktif pada } \\
\text { Pelanggan }\end{array}$ & $\begin{array}{c}\text { Seluruh data } \\
\text { pelanggan } \\
\text { muncul pada } \\
\text { halaman data } \\
\text { pelanggan } \\
\text { pelanggan }\end{array}$ & Berhasil \\
& pelangan & \\
& & & \\
\hline
\end{tabular}

\section{Pengujian Fungsi Pencarian Data Pelanggan}

Fungsi ini merupakan fungsi yang digunakan untuk mencari data pelanggan yang terdapat dalam basis data. Terdapat tiga buah kata kunci yang dapat digunakan pada fungsi ini yaitu kode pelanggan, nama pelanggan dan nama kecamatan. Berikut ini adalah screenshot saat fungsi pencarian dijalankan.

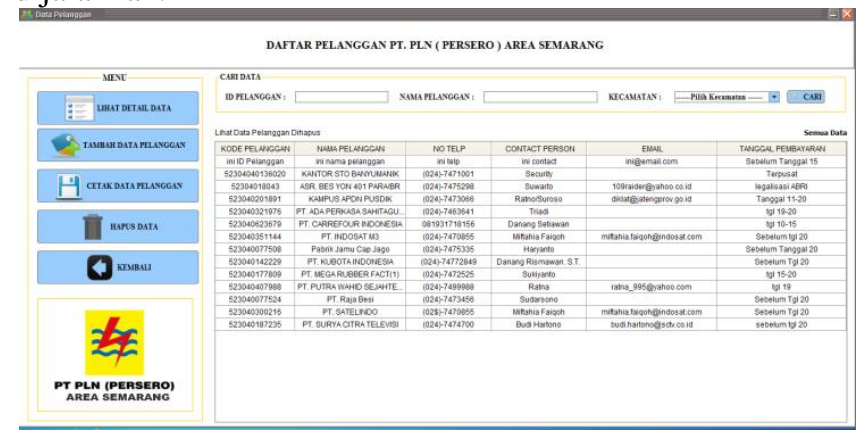

Gambar 30 Hasil pencarian data pelanggan

Tabel 4.3 Tabel pengujian fungsi pencarian data

\begin{tabular}{|c|c|c|c|}
\hline $\begin{array}{c}\text { Nama } \\
\text { Pengujian }\end{array}$ & $\begin{array}{c}\text { Bentuk } \\
\text { Pengujian }\end{array}$ & $\begin{array}{c}\text { Hasil yang } \\
\text { Diharapkan }\end{array}$ & $\begin{array}{c}\text { Hasil } \\
\text { Pengujian }\end{array}$ \\
\hline $\begin{array}{c}\text { Pengujian } \\
\text { fungsi }\end{array}$ & $\begin{array}{c}\text { Memasukkan } \\
\text { parameter } \\
\text { pencarian } \\
\text { data pada } \\
\text { halaman }\end{array}$ & $\begin{array}{c}\text { Data } \\
\text { pelanggan } \\
\text { data }\end{array}$ & becara \\
berurutan & $\begin{array}{c}\text { yang dimaksud } \\
\text { tampil pada } \\
\text { tabel data } \\
\text { pelanggan }\end{array}$ & Belanggan & \\
& & & \\
\hline
\end{tabular}

4. Pengujian Fungsi Detail Data

Fungsi ini digunakan untuk melihat detail data pelanggan dan detail data kunjungan yang ada pada basis data. Hasil dari pengujian ini adalah data tertentu yang telah dipilih oleh pengguna dapat ditampilkan secara spesifik pada aplikasi. Berikut ini adalah screenshot dari tampilan detail data pelanggan dan detail data kunjungan. 


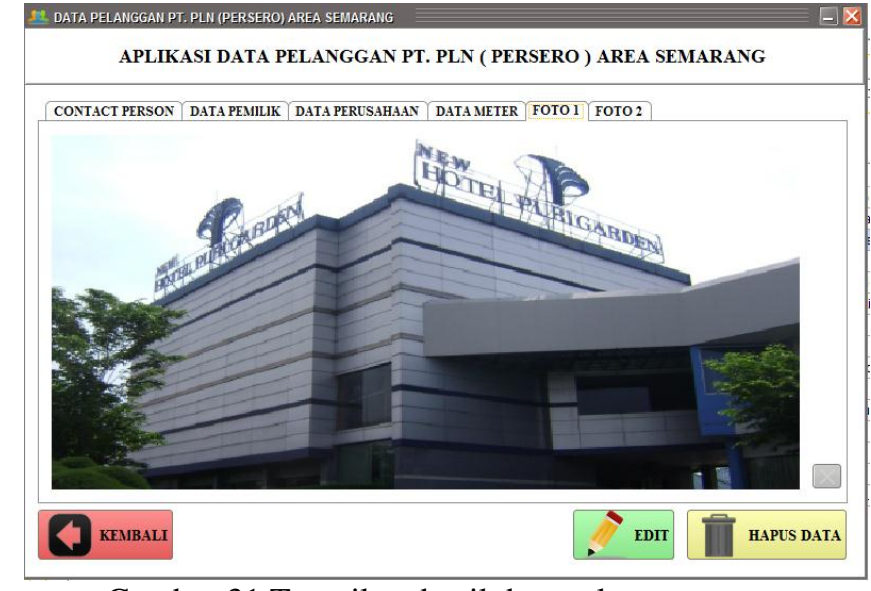

Gambar 31 Tampilan detail data pelanggan

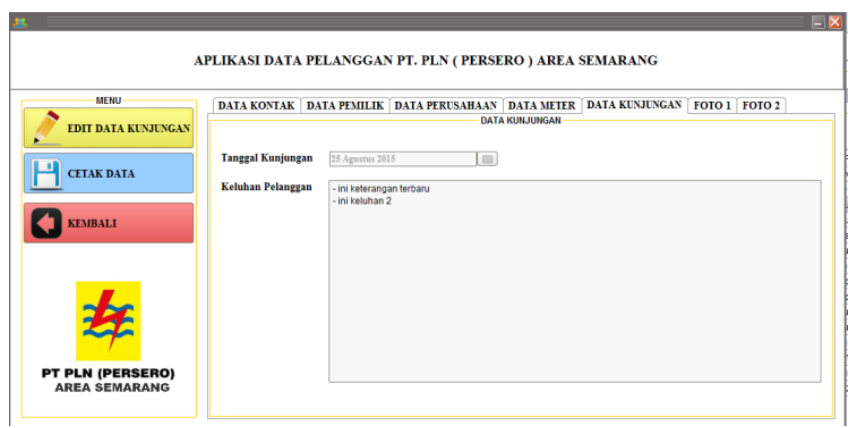

Gambar 32 Tampilan detail data kunjungan

Tabel 4.4 Tabel pengujian halaman data kunjungan

\begin{tabular}{|c|c|c|c|}
\hline $\begin{array}{c}\text { Nama } \\
\text { Pengujian }\end{array}$ & $\begin{array}{c}\text { Bentuk } \\
\text { Pengujian }\end{array}$ & $\begin{array}{c}\text { Hasil yang } \\
\text { Diharapkan }\end{array}$ & $\begin{array}{c}\text { Hasil } \\
\text { Pengujian }\end{array}$ \\
\hline $\begin{array}{c}\text { Pengujian } \\
\text { fungsi } \\
\text { melihat detail } \\
\text { data }\end{array}$ & $\begin{array}{c}\text { Melihat } \\
\text { detail data } \\
\text { kunjungan } \\
\text { secara acak }\end{array}$ & $\begin{array}{c}\text { Detai data } \\
\text { kunjungan } \\
\text { berhasil tampil } \\
\text { di halaman } \\
\text { detail } \\
\text { kunjungan }\end{array}$ & Berhasil \\
\hline $\begin{array}{c}\text { Pengujian } \\
\text { fungsi } \\
\text { melihat detail } \\
\text { data }\end{array}$ & $\begin{array}{c}\text { Melihat } \\
\text { detail data } \\
\text { pelanggan } \\
\text { pelanggan }\end{array}$ & $\begin{array}{c}\text { Detai data } \\
\text { pelanggan } \\
\text { berhasil tampil } \\
\text { di halaman } \\
\text { detail }\end{array}$ & Berhasil \\
& & pelanggan & \\
\hline
\end{tabular}

\section{Pengujian Fungsi Tambah Data}

Terdapat 2 buah fungsi untuk menambah yaitu tambah data pelanggan, tambah data kunjungan. Hasil yang diharapkan pada pengujian adalah data pelanggan dan data kunjungan dapat tersimpan pada basis data. Berikut ini adalah screenshot aktifitas menambah data pelanggan dan data kunjungan.

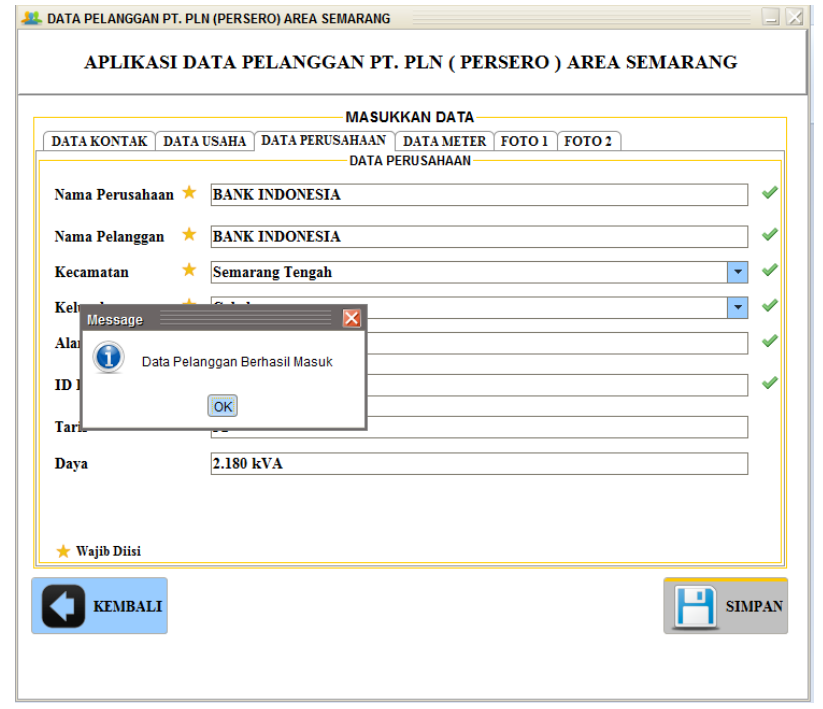

Gambar 33 Tampilan menambah data pelanggan

Pada pengujian ini tahap selanjutnya adalah menguji fungsi peringatan apabila data dengan tanda bintang tidak diisi. Hasil yang diharapkan pada aktifitas ini adalah munculnya peringatan kesalahan saat data akan disimpan. Berikut ini adalah screenshot pesan kesalahan saat menambah data

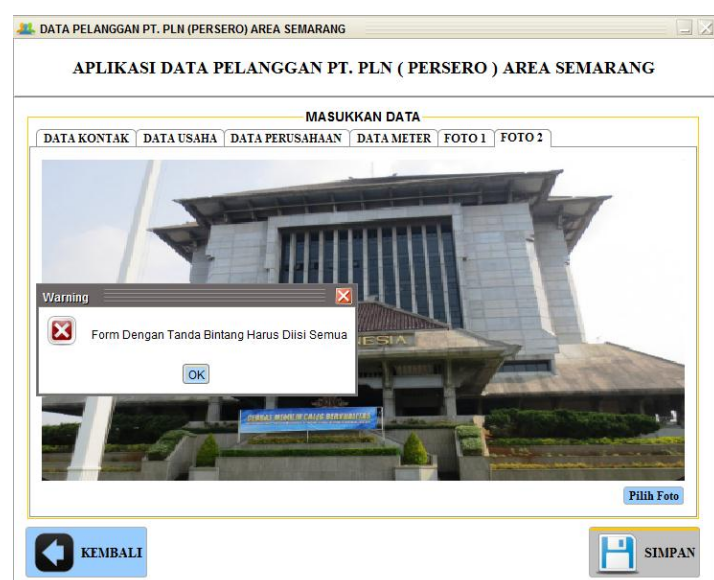

Gambar 34 Pesan kesalan saat data dengan tanda bintang tidak diisi

\section{PENUTUP}

\section{A. KESMIPULAN}

Kesimpulan yang dapat diambil dari penelitian Aplikasi Data Pelanggan Pada PT. PLN (Persero) Area Semarang yang telah dilakukan adalah sebagai berikut ini :

1. Aplikasi Data Pelanggan Pada PT. PLN (Persero) Area Semarang merupakan aplikasi yang digunakan untuk membantu menginventarisasi data pelanggan PT. PLN (Persero) Area Semarang

2. Aplikasi Data Pelanggan Pada PT. PLN (Persero) Area Semarang ini dapat membantu karyawan atau pegawai dalam melakukan pencatatan data pelanggan, data kunjungan dan data keluhan.

3. Aplikasi Data Pelanggan Pada PT. PLN (Persero) Area Semarang ini dapat membantu karyawan atau pegawai mencetak data pelanggan secara otomatis.

4. Java Runtime Environtment atau JRE merupakan sebuah platform yang digunakan untuk menjalankan aplikasi berbasis Java pada sistem operasi Windows.

5. Netbeans IDE merupakan editor yang dapat digunakan untuk merancang dan membuat program berbasis Java. 
6. Ireport merupakan sebuah plugin yang dapat digunakan untuk mendesain layout laporan sesuai dengan kebutuhan pengguna

7. Aplikasi dibuat dengan Ionic Framework dapat berjalan pada sistem operasi Android dengan versi minimum 4.0.

8. Basis data MySQL memudahkan pengguna dalam menyimpan dan mengelola data pelanggan, data kunjungan dan data keluhan.

\section{B. SARAN}

Saran yang dapat diambil dari Tugas Akhir ini adalah sebagai berikut:

1. Perlu dilakukan penelitian lebih lanjut agar aplikasi data pelanggan ini dapat berjalan pada platform lain seperti Blackberry OS, iOS dan Windows Phone

2. Perlu dilakukan penelitian lebih lanjut agar fitur - fitur pada aplikasi dapat ditambah, seperti fitur notifikasi saat data kunjungan baru telah dimasukkan, fitur pemetaan lokasi pelanggan dan fitur pendeteksi gangguan otomatis.

3. Perlu dilakukan penelitian lebih lanjut agar aplikasi dapat melakukan backup data secara otomatis saat aplikasi mengalami gangguan.

\section{DAFTAR PUSTAKA}

[1] Anisyah. 2000. Analisa dan Desain Sistem Informasi. Yogyakarta : Penerbit ANDI, 2000.

[2] Brian K, Williams \& Sawyer, Stacey C. 2005. Using Information Technology Practical Introduction to Computer \& Communications. New York, USA : McGraw Hill, 2005.

[3] C.J., Date. 2004. Pengenalan Sistem Basis Data (diterjemahkan oleh Carley Tanya). Jakarta: PT. Indeks Group Gramedia, 2004.

[4] Connoly, T.M. dan Begg, C.E. 2002. Database Systems: A Pratical Approach to Design, Implementation, and Management, edisi ke-3. Harlow : Addison-Wesley, 2002.

[5] Dhanta, Rizky. 2009. Pengantar Ilmu Komputer. Surabaya : INDAH, 2009.

[6] Febrian, Jack. 2006. Kamus Komputer dan Teknologi Informasi. Bandung : INFORMATIKA, 2006.

[7] Framework, Ionic. Ionic Framework. http://ionicframework.com. [Online] [Dikutip: 23 Januari 2015.] http://ionicframework.com/docs/guide/preface.html.

[8] Haag, S and Keen P. 1996. Information Tecnology, Tomorrow's Advantage Today. New York: McGrawHill, 1996.

[9] Hartono, Jogiyanto. 2005. Analisis \& Desain Sistem Informasi Pendekatan Terstruktur Teori dan Praktek Aplikasi Bisnis. Yogyakarta : Penerbit ANDI, 2005.

[10] Kristanto, Harianto. 2009. Konsep dan Perancangan Database. Yogyakarta : Penerbit ANDI, 2009.
[11] Kusrini. 2007. Strategi Perancangan dan Pengelolaan Basis Data. Yogyakarta : Penerbit Andi, 2007.

[12] Martin, E. 1999. Managing Information Technology What Managers Need to Know (3rd. Ed). New Jersey : Pearson Education International, 1999.

[13] Rahardjo, Budi. 2002. Memahami Teknologi Informasi. Jakarta : Elex Media Komputindo, 2002.

[14] Raharjo, Budi. 2011. Belajar Otodidak Membuat Database Menggunakan MySQL. Bandung: Informatika Bandung, 2011.

[15] Riyanto. 2010. Sistem Informasi Geografis Berbasis Mobile, . Yogyakarta : GAVA MEDIA, 2010.

[16] Riyanto, Suprapto, Indelarko, Hendy. 2008. Pengembangan Aplikasi Manajemen Database Dengan Java 2. Yogyakarta : Gava Media, 2008.

[17] Syarief, Mulkan. 2012. Bermacam Project Java Dengan IDE NetBeans. Yogyakarta: Penerbit ANDI, 2012.

[18] wikipedia.org. $2006 . \quad$ history.html. http://www.freejavaguide.com/. [Online] 2006. [Dikutip: 23 Juli 2015.$]$ http://www.freejavaguide.com/history.html.

[19] Wu C, Thomas. 2010. An introduction to objectoriented programming with Java. New York, USA : s.n., 2010. 